\title{
NATALiA BEDNARSKA
}

\section{„Edukacja w wielokulturowym świecie - doświadczenia i propozycje”}

\section{Warszawa-Cieszyn-Ustroń, 12-15 maja 2014 roku}

W dniach od 12 do 15 maja 2014 odbyła się międzynarodowa naukowa konferencja: „Edukacja w wielokulturowym świecie - doświadczenia i propozycje”. Współorganizatorami konferencji były cieszyński Wydział Etnologii i Nauk o Edukacji Uniwersytetu Śląskiego oraz Wyższa Szkoła Pedagogiczna ZNP w Warszawie.

Wspomniana konferencja jest kolejną z cyklu konferencji polsko-ukraińskich, z których pierwsza odbyła się w 2009 roku w Kijowskim Uniwersytecie imienia Borisa Grinczenki i Żytomierskim Uniwersytecie Państwowym imienia Iwana Franki. Inicjatywa spotkała się z pozytywnym odbiorem, dlatego rok po roku organizowane były kolejne konferencje: w 2010 roku przez Wyższą Szkołę Pedagogiczną ZNP w Warszawie i Akademię Pedagogiczną w Krakowie, w 2011 roku przez Akademię Humanistyczno-Pedagogiczną w Chmielnickim. Rok 2012 był bogatszy w spotkania polsko-ukraińskiej społeczności naukowej, ponieważ odbyły się dwie konferencje - gospodarzami pierwszej były Wyższa Szkoła Pedagogiczna ZNP oraz Uniwersytet w Białymstoku, a drugiej - Katedra Pedagogiki Żytomierskiego Uniwersytetu Państwowego im. Iwana Franki. W roku 2013 po raz kolejny konferencja została zorganizowana przez pracowników Kijowskiego Uniwersytetu imienia Borisa Grinczenki. Spotkaniom tym towarzyszyły różne tematy przewodnie, ale wszystkie integrowały polskich i ukraińskich naukowców wokół dwóch celów ogólnych. W czasie ich trwania prezentowane były rezultaty współpracy społeczności naukowych skupionych w Narodowej Akademii Nauk Pedagogicznych (NANP) Ukrainy i Wyższej Szkoły Pedagogicznej ZNP w Warszawie oraz współpracujących z nimi uczelni - polskich i ukraińskich. To po pierwsze. Po drugie, zostały nakreślone zadania naukowe do zrealizowania w następnym roku. Warto w tym miejscu wspomnieć, że opisany cykl konferencji jest owocem, mającej o wiele dłuższą historię, współpracy polskich i ukraińskich naukowców. Ogromne zasługi w nawiązywaniu kontaktów na- 
ukowych pomiędzy Polską a Ukrainą ma prof. dr hab. Tadeusz Lewowicki, który - pełniąc funkcję przewodniczącego Komitetu Nauk Pedagogicznych PAN - przyczynił się do zawarcia umowy pomiędzy KNP PAN a ówczesną Akademią Nauk Pedagogicznych Ukrainy (teraz: Narodową Akademią Nauk Pedagogicznych Ukrainy).

Pierwszego dnia konferencji gospodarzem była Wyższa Szkoła Pedagogiczna ZNP w Warszawie. Obrady rozpoczął rektor - senior Wyższej Szkoły Pedagogicznej ZNP w Warszawie: prof. zw. dr hab. Tadeusz Lewowicki, witając gości z Ukrainy: kierownika Laboratorium Naukowo-Badawczego Kijowskiego Uniwersytetu im. Borysa Grinczenki prof. dr hab. Switłanę Sysojewa, rektora Państwowego Uniwersytetu im. I. Franki w Żytomierzu prof. dr hab. Petro Saucha, dyrektora Oddziału Kijowskiego Instytutu Biznesu i Technologii dr Irynę Sauch, wiceprezydenta Narodowej Akademii Nauk Pedagogicznych Ukrainy prof. dr hab. Wołodymyra Łukowyj, kierownika Katedry Edukacji Przedszkolnej Kijowskiego Uniwersytetu im. Borysa Grinczenki doc. dr Gannę Bielienka, dyrektora Instytutu Społeczeństwa Kijowskiego Uniwersytetu im. Borysa Grinczenki doc. dr Kostiantyna Lynowa, prorektora ds. nauki Kijowskiego Uniwersytetu im. Borysa Grinczenki prof. dr hab. Ludmyłę Choruża, doradcę prezydenta Narodowej Akademii Nauk Pedagogicznych Ukrainy prof. dr hab. Aleksandrę Sawczenko oraz sekretarza Oddziału Pedagogiki Ogólnej i Filozofii Oświaty NANP Ukrainy prof. dr hab. Olgę Suchomlinską.

W inaugurującym konferencję wystąpieniu prof. Tadeusz Lewowicki mówił o potrzebie edukacji, która przybliżałaby społeczeństwu wartości: tolerancji, współpracy, przyjaźni i pokojowego współistnienia. Możliwości realizacji tej idei profesor przedstawił w kontekście dwóch modeli edukacji: odchodzącej w przeszłość edukacji wielokulturowej oraz edukacji międzykulturowej. Szanse zaistnienia i rozwoju tej ostatniej zostały nakreślone w odniesieniu do warunków społeczno-politycznych, gospodarczych i kulturowych. Profesor zakończył swoje wystąpienie - pełnym troski - pytaniem: idea edukacji międzykulturowej jest zrozumiała głownie w Europie, jak przekonywać do międzykulturowości poza jej granicami?

Profesor Petro Sauch wystąpił z referatem pt. „Koncepcja nowego modelu oświaty w społeczeństwie wielokulturowym". Tytułowa koncepcja została oparta na wzorze polityki demokratyczno-egalitarnej. Jej główne założenie to dialog z kulturą człowieka. Człowieka, który występuje tu w roli twórcy kultury oraz podmiotu zdolnego do kulturowego samorozwoju. Prelegent 
w swym wystąpieniu odniósł się krytycznie do pojęcia oświaty polietnicznej, którym próbowano zastąpić termin oświaty wielokulturowej.

Prof. zw. dr hab. Stefan Mieszalski, rektor WSP ZNP w Warszawie, odniósł edukację wielokulturową do zjawiska uczenia się i rozwoju dziecka. Podstawą do tych rozważań stało się założenie, że wielokulturowość to cecha środowiska społeczno-kulturowego, o wewnętrznej złożoności i zróżnicowaniu. Powołując się między innymi na teorie uczenia się Lwa S. Wygotskiego i Jerome'a Brunera, profesor udowadniał, że środowisko wielokulturowe stymuluje potrzebę uczenia się, wręcz stwarza warunki sprzyjające uczeniu się.

Punktem wyjścia wystąpienia prof. dr hab. Henryka Bednarczyka (WSP ZNP w Warszawie), zatytułowanego: Edukacja wielokulturowa w procesie pracy i kształcenia zawodowego", było założenie, że pracę zawodową należy traktować jak nieformalną edukację wielokulturową. Opierając się na wynikach badań prowadzonych w ramach projektów europejskich, profesor przedstawił wpływ globalizacji na procesy pracy i ustawicznej edukacji zawodowej.

Prof. dr hab. Olga Suchomlinska, w swym wystąpieniu zatytułowanym: „Edukacja dla społeczeństwa wielokulturowego: zamierzenia dotyczące Ukrainy", ukazała specyfikę edukacji wielokulturowej we współczesnym społeczeństwie ukraińskim i edukacji ukraińskiej. Profesor omówiła składowe ukraińskiej edukacji wielokulturowej dzieci i młodzieży.

Uszczegółowieniem wystąpienia prof. dr hab. Olgi Suchomlinskiej była prezentacja Ganny Beleńki na temat „Specyfiki wielokulturowej edukacji dzieci w wieku przedszkolnym" i jej egzemplifikacja w wieloetnicznym regionie Ukrainy - Republice Autonomicznej Krymu.

Wystąpienie dr hab. Ewy Ogrodzkiej-Mazur, prof. UŚ (Wydział Etnologii i Nauk o Edukacji UŚ w Cieszynie), zakończyło obrady w tym dniu. Prezentująca podzieliła się z wybranymi wynikami badań własnych na temat edukacji polskich dzieci w szkołach większościowych w Austrii, Czechach, Francji i Niemczech.

Przystankiem w podróży między Warszawą a Cieszynem była Jasna Góra. Uczestnicy konferencji mieli okazję zwiedzić m.in. Bibliotekę Jasnogórską, a dokładnie jej część zwaną Starą Biblioteką. Gromadzi ona około 10 tysięcy inkunabułów i starodruków. Obejrzeć można było także bogato zdobione rękopisy. Zbiory Starej Biblioteki nie są udostępniane wszystkim zwiedzającym, na wejście do tej części biblioteki trzeba uzyskać specjalną zgodę. 
Wznowienie obrad, zapoczątkowanych w Warszawie, miało miejsce w Sali Sesyjnej Ratusza Miejskiego w Cieszynie. Konferencję otworzyli gospodarze: burmistrz miasta Cieszyna mgr inż. Mieczysław Szczurek, dr hab. Zenon Gajdzica, prof. UŚ - dziekan cieszyńskiego Wydziału Etnologii i Nauk o Edukacji Uniwersytetu Śląskiego, dr hab. Urszula Szuścik, prof. UŚ - dyrektor Instytutu Nauk o Edukacji oraz prof. zw. dr hab. Tadeusz Lewowicki - przewodniczący Komitetu Naukowego Konferencji. Zainaugurowana sesja naukowa przyjęła formę dyskusji skoncentrowanej wokół tematu: „Konteksty historyczne i współczesne uwarunkowania edukacji wielo- i międzykulturowej. Dyskusję moderowali prof. zw. dr hab. Tadeusz Lewowicki oraz prof. zw. dr hab. Stefan Mieszalski. W panelu dyskusyjnym udział wzięli: prof. dr hab. Włodimir Ługowij, prof. dr hab. Olga Suchomlinska, prof. dr hab. Oleksandra Sawczenko, prof. dr hab. Petro Sauch, doc. Irina Sauch, prof. dr hab. Ludmiła Choruża, prof. dr hab. Swietłana Sysojewa, doc. Konstiantin Liniow, dr Ganna Beleńka, prof. zw. dr hab. Tadeusz Lewowicki, prof. zw. dr hab. Stefan Mieszalski, prof. zw. dr hab. Janusz Gajda, dr Maria Szybisz, dr Natalia Bednarska, mgr Bogusław Lewandowski, dr hab. Ewa Ogrodzka-Mazur, prof. UŚ, dr hab. Alina Szczurek-Boruta, prof. UŚ, dr Barbara Chojnacka-Synaszko, mgr Aleksandra Gancarz, dr Anna Gajdzica, dr hab. Barbara Grabowska, dr Urszula Klajmon-Lech, dr Łukasz Kwadrans, dr Aleksandra Minczanowska, dr Gabriela Piechaczek-Ogierman, dr Natalia M. Ruman, mgr Sylwia Ryszawy, dr Małgorzata Stokłosa, dr Anna Studenska, dr Jolanta Suchodolska, dr Janina Urban.

Warto przybliżyć niektóre z głosów w dyskusji. Wiceprezydent Narodowej Akademii Nauk Pedagogicznych Ukrainy prof. dr hab. Wołodymyr Łukowyj przedstawił w swoim wystąpieniu związki pomiędzy złożonością a samodzielnością w edukacji. Wzrastająca złożoność programów kształcenia zmusza uczniów do podejmowania w coraz szerszym zakresie samodzielności w kształceniu. Łukowyj podał przykład zmian programowych, które prowadzą do obniżenia wieku decyzji edukacyjnych.

O nasilających się zagrożeniach w wielokulturowym świecie jako trudnym wyzwaniu dla edukacji mówił w swoim wystąpieniu prof. dr hab. Janusz Gajda (WSP ZNP). Czynniki będące źródłem głównych konfliktogennych zagrożeń zostały przedstawione w podziale na dwie grupy. Uwarunkowania społeczno-polityczne, zagrożenia w sferze bytowej, odmienności kulturowe (związane ze zróżnicowaniem narodowym i religijnym), uwarunkowania doktrynalne (fanatyzm ideologiczny i religijny) to czynniki zewnętrzno-obiektywne. Czynniki subiektywne zostały opisane jako zaburzone relacje 
pomiędzy świadomością obywatelską a postawami manifestowanymi przez niektóre grupy społeczności wielokulturowych. Profesor zaprezentował autorskie propozycje na temat charakteru i głównych obszarów edukacji.

Prof. dr hab. Sysoyewa przedstawiła, jak badania ukraińskich i polskich uczonych odnoszą się do kulturologicznych problemów edukacji. Duże zasługi w tej dziedzinie przypisuje oświatologii, czyli nowemu nurtowi dociekań naukowych na Ukrainie. Badania wielokulturowości w Polsce mają dłuższą tradycję, w ich ramach najczęściej podejmowane były następujące zagadnienia: kształcenie wielowymiarowej tożsamości oraz teoria i metodyka edukacji wielokulturowej i międzykulturowej i edukacji na pograniczach.

Profesor Ludmyła Choruża podzieliła się swoimi wynikami badań na temat wartości, jakie powinien posiadać współczesny pedagog. Pani Profesor zakończyła swoje wystąpienie następującą myślą: „Jeśli chcemy być tym, kim chcemy być, to musimy przestać być tym, kim jesteśmy".

Przywoływana niejednokrotnie w czasie dyskusji wartość tolerancji pojawiła się w wystąpieniu prof. dr hab. Oleksandry Sawczenko jako ważny element treści i metod kształcenia wczesnoszkolnego. Na Ukrainie modernizacja tych treści zaczęła się w 2010 roku. Proponowane przedmioty kształcenia wczesnoszkolnego stwarzają szansę do promowania wartości tolerancji wśród dzieci.

Kolejny dzień konferencji rozpoczął się doniosłym wydarzeniem. Uczestnicy konferencji byli świadkami uroczystego podpisania przez JM Rektora Uniwersytetu Śląskiego prof. zw. dr hab. Wiesława Banysia oraz JM Rektora Państwowego Uniwersytetu im. I. Franki w Żytomierzu prof. dr hab. Petro Saucha Umowy o Współpracy pomiędzy Uniwersytetem Państwowym im. Iwana Franki w Żytomierzu a Uniwersytetem Śląskim w Katowicach. W spotkaniu oprócz uczestników konferencji wzięli udział pracownicy Wydziału Etnologii i Nauk o Edukacji: dziekan Wydziału Etnologii i Nauk o Edukacji Uniwersytetu Śląskiego - dr hab. prof. UŚ Zenon Gajdzica, dziekan Wydziału Artystycznego Uniwersytetu Śląskiego - prof. zw. Małgorzata Łuszczak, prodziekan ds. naukowych i współpracy z zagranicą WEiNoE w Cieszynie - dr hab. Ewa Ogrodzka-Mazur, prof. UŚ, dyrektor Instytutu Etnologii i Antropologii Kulturowej WEiNoE w Cieszynie - prof. zw. dr hab. Halina Rusek, dyrektor Instytutu Nauk o Edukacji WEiNoE w Cieszynie dr hab. prof. UŚ Urszula Szuścik, kierownik Zakładu Pedagogiki Społecznej i Edukacji Międzykulturowej WEiNoE w Cieszynie - dr hab. prof. UŚ Alina Szczurek-Boruta. Spotkaniu towarzyszyła wystawa książek pracowników 
Zakładu Pedagogiki Ogólnej i Metodologii Badań oraz Zakładu Pedagogiki Społecznej i Edukacji Międzykulturowej.

Wizyta na Wydziale Etnologii i Nauk o Edukacji w Cieszynie była też okazją do zwiedzania campusu UŚ. Uczestnicy konferencji przyglądali się m.in. zajęciom prowadzonym przez pracowników naukowo-dydaktycznych WEiNoE w Cieszynie.

W gościnnych progach Wydziału Etnologii i Nauk o Edukacji w Cieszynie odbyła się sesja posterowa zatytułowana: „Szkoła i szkolnictwo w środowiskach wielokulturowych, mniejszości narodowe, etniczne oraz ich funkcjonowanie”. W czasie jej trwania można było obejrzeć postery, prezentujące następujące zagadnienia: „Przysposabianie młodych ludzi do partycypacji w życiu społecznym - działania na terenie szkoły i w środowisku pozaszkolnym" (dr Barbara Chojnacka-Synaszko), „Możliwości i ograniczenia - środowisko lokalne w opinii nauczycieli pracujących w polskich szkołach poza granicami kraju” (dr Anna Gajdzica), „Zadania pedagogiki międzykulturowej a postawy Polaków wobec współczesnych repatriantów z Kazachstanu" (mgr Aleksandra Gancarz), „Odradzanie się polskiej mniejszości narodowej w niepodległej Ukrainie” (dr hab. Barbara Grabowska), „Kościół Rzymskokatolicki jako organizator i animator życia szkolnego na ziemi cieszyńskiej w XVIII i XIX wieku” (dr Urszula Klajmon-Lech), „Jedni z Wielu i RomarisingV4 - prezentacja projektu o Romach” (dr Łukasz Kwadrans), „Szkolnictwo polonijne wyzwaniem dla edukacji XXI wieku - wybrane zagadnienia" (mgr Alicja Hruzd-Matuszczyk), „Podmiotowość jednostkowa i społeczna wyzwaniem edukacji międzykulturowej - zarys wybranych zagadnień” (dr Aleksandra Minczanowska), „Edukacja dzieci w szkołach z polskim językiem nauczania - doświadczenia i problemy" (dr hab. Ewa Ogrodzka-Mazur, prof. UŚ), „Uczeń w środowisku wielokulturowym - wybrane kompetencje społeczne” (dr Gabriela Piechaczek-Ogierman), „Tydzień Kultury Beskidzkiej jako forma prezentowania i popularyzowania ludowej kultury wielu narodowości” (mgr Sylwia Ryszawy), „Rzeczywistość szkolna - perspektywa uczniów, na przykładzie wypowiedzi gimnazjalistów” (dr Małgorzata Stokłosa), „Przygotowanie przyszłych nauczycieli do pracy w warunkach wielokulturowości - prezentacja wyników realizacji projektu badawczego NCN Uczyć się od innych i uczyć-nauczać innych - praca nauczyciela w warunkach wielokulturowości (dr hab. Alina Szczurek-Boruta, prof. UŚ), „Młodzież autochtonicznych mniejszości narodowych krajów Grupy Wyszehradzkiej i jej szkoła w proce- 
sach integracyjnych Europy - prezentacja wyników realizacji projektu badawczego MNiSW (dr Janina Urban).

W drugiej części dnia uczestnicy konferencji mogli zobaczyć, jak idee edukacji wielo- i międzykulturowej realizowane są w Republice Czeskiej (sesja wyjazdowa: „Szkoła i szkolnictwo narodowościowe w Republice Czeskiej”). Goszcząc w Gimnazjum z Polskim Językiem Nauczania w Czeskim Cieszynie, naukowcy słuchali wystąpień: dr. Józefa Szymeczka, prezesa Kongresu Polaków w Republice Czeskiej, mgr Marty Kmet, dyrektor Centrum Pedagogicznego dla Polskiego Szkolnictwa Narodowościowego, oraz mgr. Andrzeja Bizonia, dyrektora Gimnazjum z Polskim Językiem Nauczania w Czeskim Cieszynie.

Międzynarodowa Naukowa Konferencja: „Edukacja w wielokulturowym świecie - doświadczenia i propozycje” służyła wymianie poglądów i doświadczeń polskiej i ukraińskiej społeczności naukowej, która będzie inspiracją do inicjonowania i kontynuowania wspólnych refleksji teoretycznych i zamierzeń badawczych. 